\begin{tabular}{ccc}
\hline & International Journal of Current Research in \\
Biosciences and Plant Biology & Volume $5 \bullet$ Number 5 (May-2018) $・$ ISSN: $2349-8080$ (Online) \\
\hline EXCELLENT \\
PUBLISHERS
\end{tabular}

\title{
Isolation and Idendification of Two Triterpenes with Larvicidal Potential in Launaea taraxacifolia (Asteracae) on Anopheles gambiae by HPLC
}

\section{A. Ahouansou1 ${ }^{1,2 *}$, G. A. Houngbèmè2 ${ }^{2}$ S. R. Mèdégan Fagla1 ${ }^{1}$ L. Catteau ${ }^{3}$, L. Fagbohoun ${ }^{2}$, S. Kotchoni ${ }^{4}$ and A. F. Gbaguidi ${ }^{1,2}$}

1Laboratoire de Chimie Organique et Pharmaceutique / Faculté des Sciences de Santé / Université d'Abomey-Calavi, 01 BP 188 Cotonou / Bénin

${ }^{2}$ Laboratoire de Pharmacognosie / Centre Béninois de Recherche Scientifique et Technique (CBRST/UAC), 01 BP 06 Oganla Porto-Novo / Benin

${ }^{3}$ Louvain Drug Research Institute (LDRI) / Université Catholique de Louvain (UCL) Avenue E. Mounier, 72(B1.72.03) 1200 Bruxelles-Belgique

${ }^{4}$ Center for Computational and Integrative Biology, Rutgers, the State University of New Jersey 315 Penn

Street, Science Builging, Camden, NJ 08102-1411

${ }^{*}$ Corresponding author.

\begin{tabular}{|c|c|}
\hline Article Info & \multirow{4}{*}{$\begin{array}{l}\text { This work provides information on the isolation and identification of two bioactive triterpenic } \\
\text { compounds in Launaea taraxacifolia (Asteracae) and their larvicidal potential. These are oleanolic } \\
\text { acid (OA) and lupeol. We prepared a hydro-methanolic extract of Launaea taraxacifolia leaves on } \\
\text { which we performed a liquid-liquid fractionation with n-hexane. The hexane fraction obtained } \\
\text { was subjected to atmospheric pressure chromatography (APC) followed by a series of TLC } \\
\text { purifications leading to the isolation of the two triterpenes. Their identification is made by means } \\
\text { of a straightforward HPLC-UV method of comparison and superposition with isocratic controls } \\
\text { in binary mode. Ursolic, oleanolic and betulinic acids (Sigma) are used as controls for the OA } \\
\text { with a mobile phase composed of } 20 \% \text { of } \mathrm{H}_{2} \mathrm{O} \text { and } 80 \% \text { of a mixture ACN/MeOH ( } 40 / 35, \mathrm{v} / \mathrm{v} \text { ) } \\
\text { and lupeol, a-amyrin, } \beta \text {-amyrin (Sigma) for lupeol with a mobile phase composed of } 5 \% \mathrm{H} \mathrm{O} \\
\text { and } 95 \% \text { ACN. The flow rate was } 1000 \mu \mathrm{L} / \mathrm{min} \text { with detection at a wavelength of } 210 \mathrm{~nm} \text {. We } \\
\text { then carried out susceptibility tests on } 3 \mathrm{rd} \text { instar Anopheles gambiae larvae from two genotypes: } \\
\text { Kisumu strain of Kenyan origin and the wild strain from Cotonou larval breeding sites. Both } \\
\text { triterpenoids were found to be active on both larval origins with lethal concentrations LC } \mathrm{C}_{50} \text { of } \\
38.12 \text { ppm in } 24 \text { hours and } 2.50 \text { ppm in } 48 \text { hours exposure for Kisumu strain; } 32.14 \text { ppm and } 2.29 \\
\text { ppm respectively in } 24 \text { hours and } 48 \text { hours for the wild population for the OA. As for lupeol, we } \\
\text { obtained LC } 50 \text { of } 105.16 \text { ppm and } 45.69 \mathrm{ppm} \text { respectively in } 24 \text { hours and } 48 \text { hours on the strain } \\
\text { Kisumu; whereas, } 103.20 \text { ppm and } 32.8 \mathrm{ppm} \text { respectively in } 24 \text { hours and } 48 \text { hours of contact for } \\
\text { wild larvae with regard to lupeol. }\end{array}$} \\
\hline $\begin{array}{l}\text { Date of Acceptance: } \\
14 \text { April } 2018 \\
\text { Date of Publication: } \\
\text { 06 May } 2018\end{array}$ & \\
\hline Keywords & \\
\hline $\begin{array}{l}\text { Anopheles gambiae } \\
\text { Larvicidal activity } \\
\text { Launaea taraxacifolia } \\
\text { Lupeol } \\
\text { Oleanolic acid }\end{array}$ & \\
\hline
\end{tabular}

C. A. Ahouansou et al. (2018) / Isolation and Idendification of Two Triterpenes with Larvicidal Potential in Launaea 


\section{Introduction}

Preventive malaria control is moving increasingly towards mosquito control, of which one of the most prominent methods is larval control. Thus, for integrated and ecologically profitable control, the use of bio-larvicides based on active extracts of plants would contribute to a significant reduction in the population of malaria vectors. The added value of larvicides when integrated with insecticidetreated bednets is that they can induce an additional reduction in infective puncture of up to $73 \%$ of the entomological inoculation rate (Fillinger et al., 2009). In addition, the development of pharmacognosy revealed the advantages of several phytochemicals with very rich and varied therapeutic effects. Recent studies conducted in Benin by Ahouansou and colleagues have shown that the hydro-methanolic extract of Launaea taraxacifolia (Asteraceae) has an inhibitory effect on the larvae of Anopheles gambiae (Ahouansou et al., 2017). Launaea taraxacifolia is a leguminous plant, edible and widely used in food in various forms and with many therapeutic effects (Dansi et al., 2008, Koukoui et al., 2015, Owoeye et al., 2015).

This study is undertaken to investigate the phytochemicals responsible for larvicidal activity in Launaea taraxacifolia. For this purpose, a liquidliquid fractionation of the hydro-methanolic extract followed by separation by atmospheric pressure chromatography (APC) was carried out. Chemical analysis by high pressure liquid chromatography (HPLC-UV) after a series of thin-layer chromotography (TLC) purifications allowed us to isolate and identify two triterpenoids that inhibit Anopheles gambiae larvae, vectors of malaria: oleanolic acid (OA) and lupeol (Figure 1).

\section{Materials and Methods}

\section{Plant collection and extract preparation}

The leaves of Launaea taraxacifolia were harvested in maize fields at Comé, southern Benin, and are identified and certified by the National Herbarium of the University of Abomey-Calavi under number: AA6689/HNB. They are then dried at $16^{\circ} \mathrm{C}$ in the laboratory for a week before being crushed and reduced to powder. At first, we extracted with 100 $\mathrm{g}$ of powder to which we added $500 \mathrm{~mL}$ of methanol-water $(70: 30 \mathrm{v} / \mathrm{v})$ with $0.5 \%$ formic acid. This mixture was homogenized and then kept under continuous stirring for 24 hours, filtered and then evaporated to dryness using a rota-vapor (Heidolph Laborota 4000 efficient). Then, $2.5 \mathrm{~g}$ of the hydromethanolic extract obtained was dissolved in 150 $\mathrm{ml}$ of methanol-water mixture $(1: 3, \mathrm{v} / \mathrm{v})$. This solution was washed three times with $100 \mathrm{ml}$ of nhexane by washing with a separating funnel. The hexane fraction $\left(\mathrm{F}_{\mathrm{Hex}}\right)$ obtained after this liquidliquid fractionation process was reduced to dryness by means of a rota-vapor apparatus.

\section{APC splitting and compound isolation}

We poured $100 \mathrm{~g}$ of Merck® silica gel (0.063-0.20 $\mathrm{mm}$ ) into a glass column of $2 \mathrm{~cm}$ in diameter and $80 \mathrm{~cm}$ in height to which we added $300 \mathrm{ml}$ of methanol, which was left for 24 hours. Conditioning is done with $200 \mathrm{~mL}$ of $100 \% \mathrm{n}$ hexane cast along the stationary phase and collected in a vial. Then, $300 \mathrm{mg}$ of the $\mathrm{F}_{\mathrm{Hex}}$ fraction was eluted throughout the stationary phase with increasing solvent polarity gradients of $100 \mathrm{ml}$ of volume each in the following order:

Hexane $100 \%$

Hexane-ethyl acetate-glacial acetic acid (8-1-1, $\mathrm{v} / \mathrm{v} / \mathrm{v})$

Hexane-ethyl acetate-glacial acetic acid (6-3-1, $\mathrm{v} / \mathrm{v} / \mathrm{v})$

Drain with $100 \%$ ethyl acetate

The collection rate is $5 \mathrm{~mL} /$ tube at 1 drop / second.

After a regroupment of fractions based on the TLC chromatographic profile of the contents of the tubes numbered T1 to T80, two subfractions named T11- 
21 and T31-38, each having two distinct spots were selected on the basis of their physical characteristics.

Then, we did a preparative TLC at the end of which we chose one (1) spot of each subfraction with regard to its sharpness followed by filtration on SPE cartridge. One of the filtrates obtained is concentrated in acetonitrile (ACN) leading to the compound M1 while the other in the n-hexane leading to the compound M2, before being separated by chromatography on Sephadex LH20 gel.

At the end of this series of chromatographic methods, we came up to a white amorphous powder after evaporation to dryness in a test tube of the two compounds M1 and M2, which have the same physical characteristics as TLC parameters oleanolic acid and lupeol (Sigma Aldrich 99\%). Spots were evidenced with the well-known sulfuric anisaldehyde reagent which colors the pure compounds M1 and M2 in purplish pink.

\section{HPLC identification of M1 and M2 molecules}

The HPLC system used for the identification of M1 and M2 molecules is equipped with a Merck Hitachi pump, an autosampler, a UV detector (LambdaMax, model 481). The column used is Phenomenex Luna C18 250 x $4.6 \mathrm{~mm}^{2}$ which contains particles of $5 \mu \mathrm{m}$ in size.

\section{M1 identification}

Standards solutions: $500 \mu \mathrm{L}$ of ursolic, oleanolic and betulinic acids (Sigma) at $1 \mathrm{mg} / \mathrm{mL}$ were spiked with $500 \mu \mathrm{L}$ of M1 solution $(1 \mathrm{mg} / \mathrm{mL})$.

The identification of M1 was performed using a method recently published to quantitate UA and OA with some modifications (Catteau et al., 2017).

The flow rate was $1000 \mu \mathrm{L} / \mathrm{min}$ using an isocratic binary solvent system: solvent $\mathrm{A}(20 \%), \mathrm{H}_{2} \mathrm{O}$ pH6 $\left(\mathrm{CH}_{3} \mathrm{COONH}_{4} 0.02 \mathrm{M}\right)$; solvent B (80\%), $\mathrm{ACN} / \mathrm{MeOH}$ 40:35. Peaks were detected at 210nm.

\section{M2 identification}

Standards solutions: $500 \mu \mathrm{L}$ of lupeol, $\alpha$-amyrin, $\beta$ amyrin (Sigma) at $1 \mathrm{mg} / \mathrm{mL}$ were spiked with $500 \mu \mathrm{L}$ of $\mathrm{M} 2$ solution $(1 \mathrm{mg} / \mathrm{mL})$.

The flow rate was $1000 \mu \mathrm{L} / \mathrm{min}$ using an isocratic binary solvent system: solvent A (5\%), $\mathrm{H}_{2} \mathrm{O}$ pH6 $\left(\mathrm{CH}_{3} \mathrm{COONH}_{4} 0.02 \mathrm{M}\right)$; solvent $\mathrm{B}(95 \%)$, ACN. Peaks were detected at $210 \mathrm{~nm}$.

\section{Larval susceptibility tests on Anopheles gambiae}

Bioassays were carried out on two larval strains: wild larvae collected in larval breeding sites in Cotonou according to the morphological and behavioral criteria of the larvae using taxonomic determination keys (Gillies and Coetzee, 1987) and the larvae Kisumu of Kenyan origin obtained at the Entomological Research Center of Cotonou (CREC). Kisumu larvae have been kept in culture at the CREC laboratory for several years and their sensitivity is regularly checked. The WHO standard protocol for larval susceptibility testing against insecticides used in control campaigns has been exploited with a slight modification in line with our working conditions (WHO, 2005). The larvae were treated with solutions of M1 and M2 compounds in a concentration range of 25 to $200 \mathrm{ppm}$, prepared with 2\% DMSO (dimethyl sulfoxide). The tests were carried out in transparent cups $5 \mathrm{~cm}$ in diameter, each containing $100 \mathrm{~mL}$ of solution and 20 larvae of Anopheles gambiae at the 3rd stage of life. The same number of larvae was placed in another control beaker containing only $100 \mathrm{~mL}$ of $2 \%$ DMSO. For each of the concentrations of M1 and M2 as well as for the control, three replicates were performed. The behavior of the larvae, by counting the number of survivors, was monitored for 48 hours and the lethal concentrations $\left(\mathrm{LC}_{50}\right)$ were determined every 24 hours. Indeed, are considered as dead, the larvae that remain immobile even in contact with a needle and those also who are moribund.

The analysis of the data is done using SPSS 21.0 statistic software in Probit model at the risk of 5\% 
( $\mathrm{P}<0.05$ ) aiming at determining the average mortality rate of anopheles larvae following the doses applied in order to extract the lethal concentrations $\left(\mathrm{LC}_{50}\right)$.

\section{Results and Discussion}

\section{Identification of M1 and M2}

Both compounds M1 and M2 were isolated from the hydro-methanolic extract of Launaea taraxacifolia by liquid-liquid fractionation followed by APC and identified by HPLC -UV analysis by co-elution with controls (Figure 2 and 3 ).

Figures 2 and 3 show the chromatographic profile of standards and compounds M1 and M2. The chromatogram obtained with the solution formed by the mixture of the oleanolic acid standard (Sigma) and the compound M1 has a single peak at $38 \mathrm{~min}$ which is also present at the level of the other chromatograms at the same retention time with the peak of ursolic, and betulinic acid standards (Figure 2). Compound M1 is therefore oleanolic acid.

The chromatogram obtained with the solution formed by the mixture of the lupeol standard (Sigma) and the compound M2 has a single peak at 64 min which is also present at the level of the other chromatograms at the same retention time with the peak of $\alpha$-amyrin and $\beta$-amyrin standards (Figure 3). Compound M2 is therefore lupeol.

\section{Larvicidal actitvity of M1 and M2}

The lethal concentrations $50\left(\mathrm{LC}_{50}\right)$ obtained after the biological screening of the compounds M1 and M2 on the larvae of Anopheles gambiae are recorded in Table I. We note from reading this table that the $\mathrm{LC}_{50}$ values obtained with the compound M1 is significantly lower than those of the compound M2 regardless of the exposure time and the origin of the larvae considered with the lowest value ( $2.29 \mathrm{ppm})$ held after 48 hours of contact.

Table 1. $\mathrm{LC}_{50}$ values in ppm of the M1 and M2 compounds on the larvae.

\begin{tabular}{|c|c|c|c|c|c|c|c|c|}
\hline & \multicolumn{4}{|c|}{ Kisumu } & \multicolumn{4}{|c|}{ Wild } \\
\hline & \multicolumn{2}{|c|}{ M1 } & \multicolumn{2}{|c|}{ M2 } & \multicolumn{2}{|c|}{ M1 } & \multicolumn{2}{|c|}{ M2 } \\
\hline & $24 \mathrm{~h}$ & $48 \mathrm{~h}$ & $24 \mathrm{~h}$ & $48 \mathrm{~h}$ & $24 \mathrm{~h}$ & $48 \mathrm{~h}$ & $24 \mathrm{~h}$ & $48 \mathrm{~h}$ \\
\hline $\mathbf{L C}_{\mathbf{5 0}}$ & 38.12 & 2.50 & 105.16 & 45.69 & 32.14 & 2.29 & 103.20 & 32.38 \\
\hline
\end{tabular}
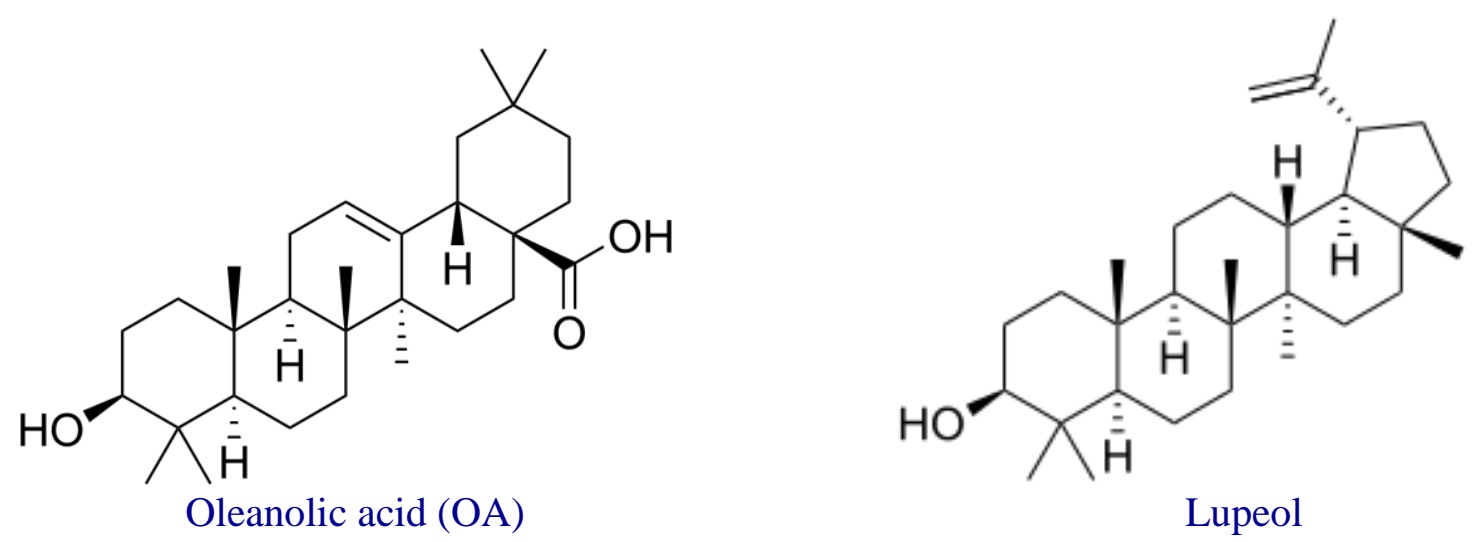

Fig. 1: Chemical structure of oleanolic acid and lupeol. 


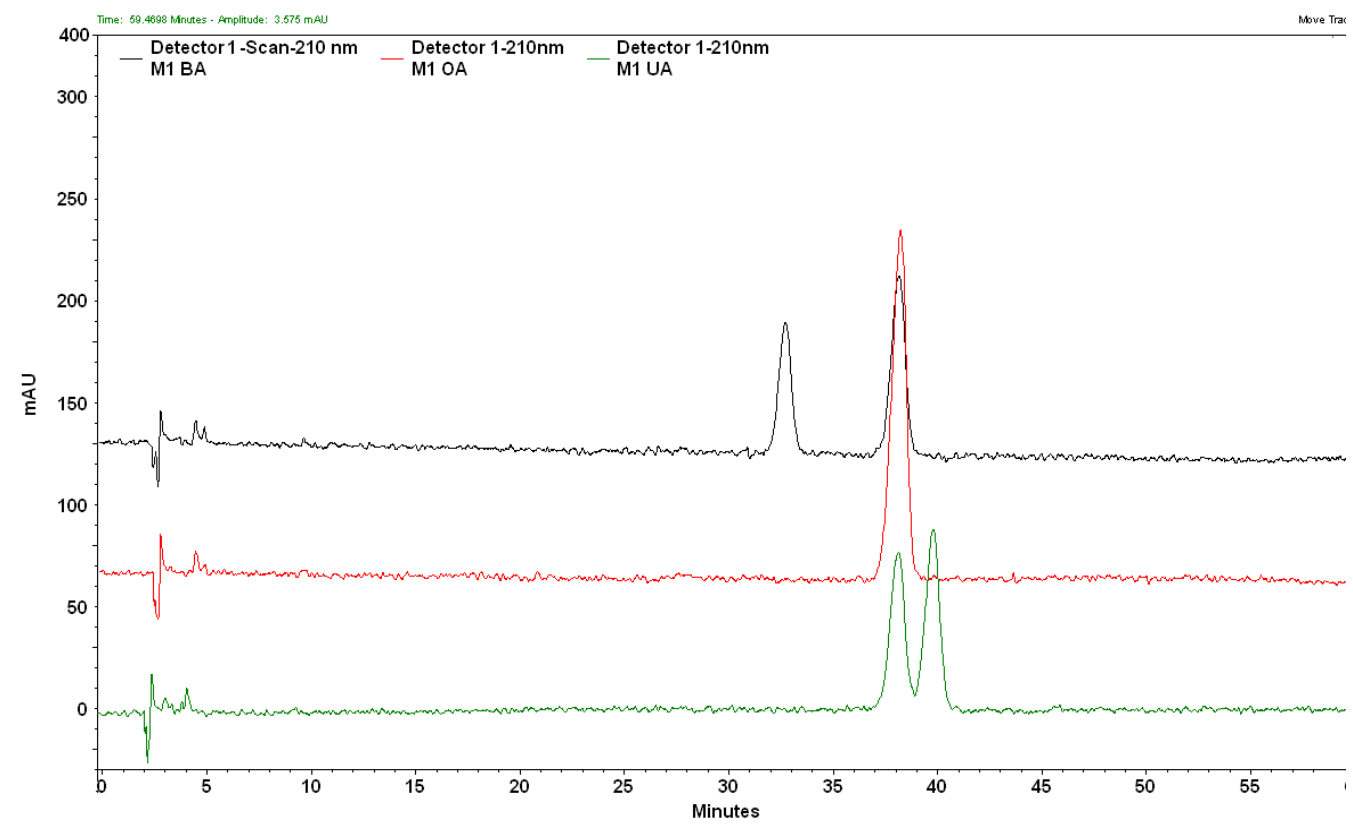

Fig. 2: M1 identification chromatograms.

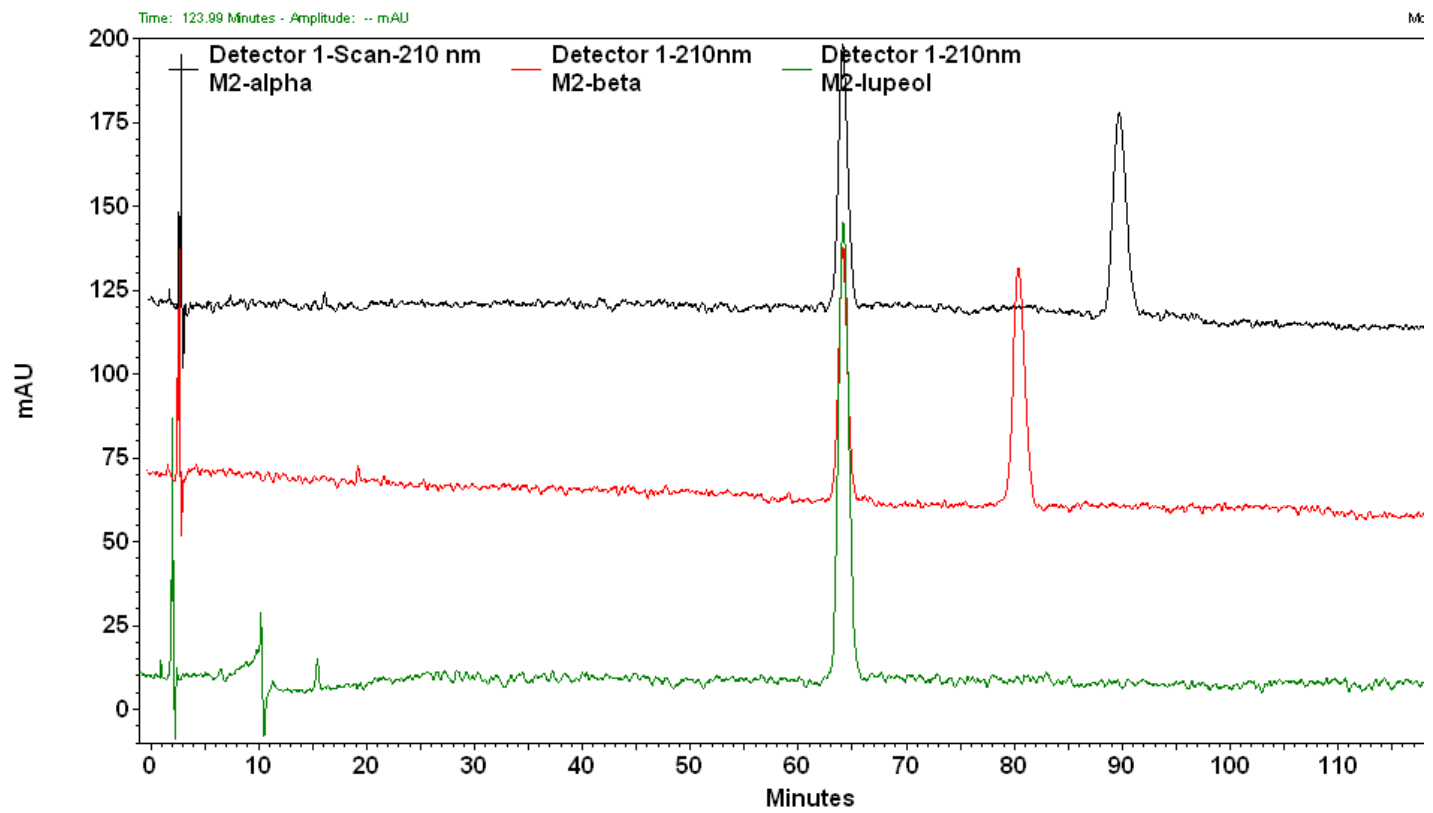

Fig. 3: M2 identification chromatograms.

In addition to its manifold therapeutic activities (antioxidant, antimicrobial and antiviral properties) widely proven by scientific research (Dansi et al., 2008, Gbadamosi et al., 2012, Arawande et al., 2013, Owoeye et al., 2015, Adimonyemma et al., 2016), Launaea taraxacifolia also has an inhibitory effect on Anopheles gambiae larvae (Ahouansou et al., 2016, Ahouansou et al., 2017). As part of the development of phyto-larvicides beneficial to the environment and targeting mosquitoes resistant to chemical insecticides, it is necessary to search and identify the main phytochemicals responsible for 
larvicidal activity. In this study, we first performed a liquid-liquid fractionation of the hydromethanolic extract of Launaea taraxacifolia with nhexane. The hexane fraction $F_{H e x}$ obtained was fractionated further by atmospheric pressure chromatography leading to different sub-fractions. The latter have undergone a series of thin layer chromatographies which led to the isolation of two molecules, namely M1 and M2 after purification and revelation with sulfuric anisaldehyde. These isolated molecules of Launaea taraxacifolia whose phytochemical screening reveals the presence of triterpenic compounds (Dansi et al., 2012, Koukoui et al., 2015), have the same physical characteristics TLC as the chromatograms of acid oleanolic and lupeol (Sigma Aldrich 99\%) used as control molecules. The identification of the molecules M1 and M2 is done by means of a HPLC-UV method in co-elution mode and by comparison and superposition of the chromatograms of each molecule with standards. The conformity of the chromatograms of the isolated compounds and those of the controls confirms the purity of the molecules M1 and M2. Our results showed that the molecule M1 is oleanolic acid and the molecule M2 is lupeol. These two phytochemical molecules of terpenic nature possess important known pharmacological effects. OA is a multifunctional triterpenoid pentacyclic (isomer of ursolic acid) ubiquitous, widespread in several food and medicinal plant species. It is endowed of various properties such as antioxidant, anti-inflammatory, spasmolytic, antiallergic, acetylcholinesterase inhibitor, alpha-glucosidase, antimicrobial, antiviral, immunomodulatory, cytotoxic, antitumor, anti-angiogenic, hepatoprotective, antipruritic (Jesus et al., 2015). Other specific studies have shown that OA is active on Dermatophilus congolensis (bacterium causing dermatosis) (Gbaguidi et al., 2005) and inhibits the actions of Mycobacterium tuberculosis H37Rv (JimenezArellanes et al., 2013). Lupeol has various medicinal properties, including anti-inflammatory, but also anti-protozoan, antimicrobial, antitumor, and chemotherapic properties (Prasad et al., 2008); it is effective in laboratory models as an inhibitor of skin cancer (Saleem et al., 2004). The identification method used is inspired by that used by Catteau and colleagues for the identification of oleanolic and ursolic acids in Vitellaria paradoxa (Catteau et al., 2017). The $\mathrm{LC}_{50}$ of the $\mathrm{OA}$ and lupeol obtained after the biological screening are significantly lower than those obtained with the hydro-methanolic extract used for the isolation of the compounds: $182.68 \mathrm{ppm}$ and $135.13 \mathrm{ppm}$ respectively in 24 hours and 48 hours on Kisumu larvae against $157.36 \mathrm{ppm}$ and $116.88 \mathrm{ppm}$ on wild larvae respectively in 24 hours and 48 hours of contact (Ahouansou et al., 2017). Our results are similar to those obtained previously with the essential oils of Cinnamomum osmophloeum and Cryptomeria japonica on the larvae of Anopheles gambiae SS with $\mathrm{LC}_{50}$ respectively of 58.15 and $63.92 \mu \mathrm{g} / \mathrm{mL}$ at the same exposure times (Mdoe et al., 2014b, Mdoe et al., 2014a). Earlier and similar works were done in Cameroon with the essential oils of a number of plants, the most effective giving an $\mathrm{LC}_{50}$ of $18 \mathrm{ppm}$ in 24 hours of activity on 4th instar larvae of $A n$. gambiae (Tchoumbougnang et al., 2009). On the other hand, Kisumu and wild larvae practically adopt the same behavior with respect to each compound. OA and lupeol are therefore responsible for larvicidal activity in Launaea taraxacifolia. Nevertheless, the $\mathrm{LC}_{50}$ values obtained with the compound M1 are significantly lower than those of the compound M2 regardless of the exposure time and the origin of the larvae considered with the lowest value $(2.29 \mathrm{ppm})$ held after $48 \mathrm{~h}$ of contact. $\mathrm{OA}$ is therefore more active on An. gambiae larvae. These results are encouraging in view of the resistance observed at the level of An. gambiae with respect to certain chemical insecticides of the group of organophosphorus compounds, pyrethroids and carbamates (Djogbenou et al., 2011, Edi et al., 2012, Nwane et al., 2013). Also, we intend to develop a method of direct extraction of these two triterpenoids in order to determine them quantitatively for a better standardization of the use of this plant.

This work revealed the presence of two triterpene compounds known for their pharmacological activities in Launaea taraxacifolia. The discovery of their larviciding potential strengthens their 
therapeutic potential in the integrated fight against malaria. Launaea taraxacifolia is therefore a good candidate in the formulation of a bio-larvicide. This method of control will be able to solve the question of resistance of malaria vectors on the one hand and the protection of the environment on the other hand.

\section{Conflict of interest statement}

The authors have no conflict of interest.

\section{Acknowledgement}

We thank Prof. Joelle Quetin-Leclercq UCL/ Belgium for technical assistance; Prof. Jacques Poupaert UCL/ Belgium for proofreading the English version of the manuscript and Razacky OSSE PhD, for their cooperation in entomological investigations.

\section{References}

Adimonyemma, N. R., Chukwuma, O. M., Akachukwu, E. E., Iroka, F. C., 2016. Phytochemical analysis and antibacterial activity of Launaea taraxacifolia ethanolic leaves extract. Scholars Acad. J. Biosci. 4(3A), 193-196.

Ahouansou, C. A., Fagbohoun, L., Mèdégan Fagla, S., Houngbèmè, G. A., Kotchoni, S., Gbaguidi, A. F., 2017. Inhibition effects of Elaeis oleifera (Arecaceae) and Launaea taraxacifolia (Asteraceae) on two genotypes of Anopheles gambiae larvae. Int. J. Curr. Res. Biosci. Plant Biol. 4, 39-46.

Ahouansou, C. A., Fagbohoun, L., Mèdégan Fagla, S. R., Tchètchè, J., Kotchoni, S., Gbaguidi, A. F., 2016. Phytochemical analysis, toxicity and larvicidal activity of extracts from Launaea taraxacifolia (Asteraceae) on Anopheles gambiae, a malaria vector. Int. J. Vector Borne Dis. 107, 130-138.

Arawande, J. O., Amoo, I. A., Lajide, L., 2013. Chemical and phytochemical composition of wild lettuce Launaea taraxacifolia. J. Appl. Phytotechnol. Environ. Sanit. 2, 25-30.

Catteau, L., Reichmann, N. T., Olson, J., Pinho, M.
G., Nizet, V., Van Bambeke, F., QuetinLeclercq, J., 2017. Synergy between ursolic and oleanolic acids from Vitellaria paradoxa leaf extract and beta-lactams against methicillinresistant Staphylococcus aureus: In vitro and in vivo activity and underlying mechanisms. Molecules. 22(12), pii: E2245.

Dansi, A., Adjatin, A., Adoukonou-Sagbadja, H., Faladé, V., Yedomonhan, H., Odou, D., Dossou, B., 2008. Traditional leafy vegetables and their use in the Benin Republic. Genet. Resour. Crop Evol. 55, 1239-1256.

Dansi, A., Vodouhe, R., Azokpota, P., Yedomonhan, H., Assogba, P., Adjatin, A., Loko, Y. L., Dossou-Aminon, I., Akpagana, K., 2012. Diversity of the neglected and underutilized crop species of importance in Benin. Scient. World J. 2012, 932947.

Djogbenou, L., Pasteur, N., Akogbeto, M., Weill, M., Chandre, F., 2011. Insecticide resistance in the Anopheles gambiae complex in Benin: a nationwide survey. Med. Vet. Entomol. 25, 256267.

Edi, C. V., Koudou, B. G., Jones, C. M., Weetman, D., Ranson, H., 2012. Multiple-insecticide resistance in Anopheles gambiae mosquitoes, Southern Cote d'Ivoire. Emerg. Infect. Dis. 18, 1508-1511.

Fillinger, U., Ndenga, B., Githeko, A., Lindsay, S. W., 2009. Integrated malaria vector control with microbial larvicides and insecticide-treated nets in western Kenya: A controlled trial. Bull. World Health Organ. 87, 655-665.

Gbadamosi, I. T., Alia, A. E. \& Okolosi, O. 2012. In vitro antimicrobial activities and nutritional assessment of roots of ten Nigerian vegetables. New York Sci. J. 5(12), 234-240.

Gbaguidi, F., Accrombessi, G., Moudachirou, M., Quetin-Leclercq, J., 2005. HPLC quantification of two isomeric triterpenic acids isolated from Mitracarpus scaber and antimicrobial activity on Dermatophilus congolensis. J. Pharm. Biomed. Anal. 39, 990-995.

Gillies, M. T., Coetzee, M., 1987. A supplement to the Anophelinae of Africa South of the Sahara. Publ. of the South African Institute for Medical Research. pp.55-143. 
Jesus, J. A., Lago, J. H., Laurenti, M. D., Yamamoto, E. S., Passero, L. F., 2015. Antimicrobial activity of oleanolic and ursolic acids: an update. Evid. Based Compl. Altern. Med. 2015, 620472.

Jimenez-Arellanes, A., Luna-Herrera, J., CornejoGarrido, J., Lopez-Garcia, S., Castro-Mussot, M. E., Meckes-Fischer, M., Mata-Espinosa, D., Marquina, B., Torres, J., Hernandez-Pando, R., 2013. Ursolic and oleanolic acids as antimicrobial and immunomodulatory compounds for tuberculosis treatment. BMC Compl. Altern. Med. 13, 258.

Koukoui, O., Agbangnan, P., Boucherie, S., Yovo, M., Nusse, O., Combettes, L., Sohounhloué, D., 2015. Phytochemical study and evaluation of cytotoxicity, antioxidant and hypolipidemic properties of Launaea taraxacifolia leaves extracts on cell lines HepG2 and PLB985. Am. J. Plant Sci. 6, 1768-1779.

Mdoe, F. P., Cheng, S. S., Lyaruu, L., Nkwengulila, G., Chang, S. T., Kweka, E. J., 2014 a. Larvicidal efficacy of Cryptomeria japonica leaf essential oils against Anopheles gambiae. Parasit. Vectors. 7, 426.

Mdoe, F. P., Cheng, S. S., Msangi, S., Nkwengulila, G., Chang, S. T., Kweka, E. J., 2014b. Activity of Cinnamomum osmophloeum leaf essential oil against Anopheles gambiae s.s. Parasit. Vectors. 7, 209.
Nwane, P., Etang, J., Chouasmall Yi, U. M., Toto, J. C., Koffi, A., Mimpfoundi, R., Simard, F., 2013. Multiple insecticide resistance mechanisms in Anopheles gambiae s.l. populations from Cameroon, Central Africa. Parasit. Vectors. 6, 41.

Owoeye, O., Femi-Akinlosotu, O. M., Adejuwon, S. A., 2015. Launaea taraxacifolia aqueous extract attenuates cisplatin-induced neurotoxicity by decreasing oxidative stress and neuronal cell death in rats. Arch. Basic Appl. Med. 3, 71-78.

Prasad, S., Kalra, N., Singh, M., Shukla, Y., 2008. Protective effects of lupeol and mango extract against androgen induced oxidative stress in Swiss albino mice. Asian J. Androl. 10, 313318.

Saleem, M., Afaq, F., Adhami, V. M., Mukhtar, H., 2004. Lupeol modulates NF-kappa B and PI3K/Akt pathways and inhibits skin cancer in CD-1 mice. Oncogene. 23, 5203-5214.

Tchoumbougnang, F., Dongmo, P. M. J., Sameza, M. L., Mbanjo, E. G. N., Fotso, G. B. T., Zollo, P. H. A., Menut, C., 2009. Activité larvicide sur Anopheles gambiae Giles et composition chimique des huiles essentielles extraites de quatre plantes cultivées au Cameroun. Biotechnol. Agron. Soc. Environ. 13, 77- 84.

WHO 2005. Guidelines for Laboratory and Field Testing of Mosquito Larvicides, Geneva.

\section{How to cite this article:}

Ahouansou, C. A., Houngbèmè, G. A., Mèdégan Fagla, S. R., Catteau, L., Fagbohoun, L., Kotchoni, S., Gbaguidi, A. F., 2018. Isolation and idendification of two triterpenes with larvicidal potential in Launaea taraxacifolia (Asteracae) on Anopheles gambiae by HPLC. Int. J. Curr. Res. Biosci. Plant Biol. 5(5), 17-24. doi: https://doi.org/10.20546/ijcrbp.2018.505.003 